\title{
Analisis Ketidaklengkapan Pengisian Lembar Informed Consent Pasien Bedah di Rumah Sakit Tk. III dr. Reksodiwiryo Padang
}

\author{
Dewi Oktavia ${ }^{1}$, Hardisman $^{2}$, Erkadius ${ }^{3}$ \\ ${ }^{1}$ Apikes Iris, ${ }^{2,3}$ Universitas Andalas \\ 1'dewioktavia8780@gmail.com \\ ${ }^{2}$ Erkadius@yahoo.com, ${ }^{3}$ Hardisman@gmail.com
}

\begin{abstract}
One indicator of the minimum standards service medical record is the complete filling of an informed consent sheet of 100\%. Based on the initial survey at the 3rd Level Hospital of Dr.Reksodiwiryo Padang, it was found that from the 20 informed consent sheets, the average number of incomplete informed consent forms was $29 \%$. The purpose of this study was to determine the number of completeness and causes of incomplete filling of surgical patients' informed consent sheets at the 3rd Level Hospital of Dr.Reksodiwiryo Padang. This study is a mixed methods research with sequential explanatory design carried out at the 3rd Level Hospital of Dr.Reksodiwiryo Padang in March to July 2017. In quantitative research, the sampling technique was simply random sampling, sample number 67, and the analysis used was descriptive. While the qualitative research technique for determining informants was used by purposive sampling, the number of informants was 15 people, and the analysis used content analysis techniques. The results of quantitative research obtained an average informed consent score of 66,3\% optimal and the process in the implementation of the medical record has not been implemented properly. The conclusion of this study is the number of completeness in filling out the information sheet of the medical record has not reached the SPM medical record in the hospital. This is because the implementation of the medical record service system is not optimal.
\end{abstract}

Keywords: Informed Consent, Hospital, Minimum Standards Service

\begin{abstract}
Abstrak
Salah satu indikator Standar Pelayanan Minimal (SPM) rekam medis adalah kelengkapan pengisian lembar informed consent sebesar 100\%. Berdasarkan survey awal di Rumah Sakit Tk.III dr.Reksodiwiryo Padang ditemukan bahwa dari 20 lembar informed consent rata-rata angka ketidaklengkapan pengisian lembar informed consent sebesar 29\%. Tujuan penelitian ini adalah untuk mengetahui angka kelengkapan dan penyebab ketidaklengkapan pengisian lembar Informed consent pasien bedah di Rumah Sakit Tingkat III. dr.Reksodiwiryo Padang. Penelitian ini merupakan penelitian kombinasi (mixed methods research) dengan desain sequential explanatory yang dilaksanakan di Rumah Sakit Tk.III dr. Reksodiwiryo Padang pada bulan Maret sampai dengan Juli 2017. Pada penelitian kuantitatif, teknik pengambilan sampel dengan simple random sampling, jumlah sampel 67, dan analisis yang digunakan deskriptif. Sedangkan penelitian kualitatif teknik penentuan informan yang digunakan secara purposive sampling, jumlah informan 15 orang, dan analisis yang digunakan tekhnik analisis isi. Hasil penelitian kuantitatif diperoleh rata-rata angka kelengkapan informed consent diperoleh $66,3 \%$. Hasil Penelitian kualitatif diperoleh input penyelenggaraan sistem pelayanan rekam medis belum optimal dan proses dalam pelaksanaan rekam medis belum terlaksana dengan baik. Kesimpulan penelitian ini adalah angka kelengkapan pengisian lembar Informed Consent rekam medis belum mencapai SPM rekam medis di rumah sakit. Hal ini disebabkan karena penyelenggaraan sistem pelayanan rekam medis belum optimal.
\end{abstract}

Kata kunci: Informed Consent, Rumah Sakit, Standar Pelayanan Minimal 


\section{PENDAHULUAN}

Pelayanan kesehatan merupakan hak setiap orang yang dijamin dalam Undang-Undang Dasar Negara Republik Indonesia (UUD RI) tahun 1945 yang harus diwujudkan dengan upaya peningkatan derajat kesehatan masyarakat yang setinggi-tingginya. Rumah sakit merupakan salah satu sarana pelayanan kesehatan masyarakat yang memiliki peran yang sangat penting dalam meningkatkan derajat kesehatan masyarakat. Rumah sakit menurut Undang-Undang Nomor 44 Tahun 2009 adalah sarana kesehatan yang menyelenggarakan pelayanan kesehatan perorangan yang meliputi pelayanan promotif, preventif, kuratif, dan rehabilitatif (DPR RI, 2009).

Agar rumah sakit dapat melaksanakan fungsi dengan baik, maka rumah sakit dituntut untuk memberikan pelayanan yang bermutu sesuai dengan standar yang telah ditetapkan. Berdasarkan Kemenkes RI Nomor 129/Menkes/SK/II/2008 bahwa mutu atau kualitas adalah kepatuhan terhadap standar yang telah ditetapkan atau sesuai dengan persyaratan. Standar Pelayanan Minimal (SPM) Rumah Sakit merupakan suatu ketentuan-ketentuan bagi rumah sakit yang dikeluarkan oleh Menteri Kesehatan Republik Indonesia dalam rangka usaha pemerintah untuk menjamin mutu pelayanan rumah sakit (Kemenkes RI, 2008).

Salah satu yang berperan penting dalam suatu rumah sakit adalah bagian dari intalasi perekam medis atau disebut dengan medical record. Berdasarkan Permenkes No. 269/Menkes/Per/III/ tahun 2008 tentang Rekam Medis menyebutkan bahwa semua fasilitas pelayanan kesehatan wajib menyelenggarakan rekam medis, termasuk rumah sakit (Permenkes RI, 2008). Kemudian disusul lagi dengan dikeluarkannya Undang-Undang (UU) No 44 tahun 2009 tentang Rumah Sakit, ada kejelasan bagi rumah sakit menyangkut kewajibannya untuk menyelenggarakan rekam medis (DPR RI, 2009).

Pelayanan rekam medis peranannya sangat penting karena merupakan bukti tertulis dari pelayanan kesehatan yang diterima pasien. Hal ini didukung dengan isi Permenkes RI Nomor 269/MENKES/ PER/III/2008 Pasal 1 ayat 1 bahwa rekam medis adalah berkas yang berisikan catatan dan dokumen tentang identitas pasien, pemeriksaan, pengobatan, tindakan dan pelayanan lain yang telah diberikan kepada pasien (Permenkes RI, 2008).
Salah satu SPM rekam medis di rumah sakit menurut Kemenkes RI tahun 2008 adalah kelengkapan informed consent setelah mendapatkan informasi yang jelas sebesar 100\% (Kemenkes RI, 2008). Menurut Permenkes RI No. 290/MENKES/PER/ III/2008 informed consent merupakan persetujuan tindakan kedokteran yang diberikan oleh pasien atau keluarga terdekatnya setelah mendapatkan penjelasan secara lengkap mengenai tindakan kedokteran yang akan dilakukan terhadap pasien tersebut. Rekam medis mempunyai kekuatan hukum sebagai salah satu unsur masukan dalam proses pengambilan keputusan oleh hakim, sehingga rekam medis yang selesai dibuat tidak boleh diubah, dihilangkan, atau ditambah isinya.

Kelengkapan lembar informed consent dapat digunakan untuk berbagai keperluan. Keperluan tersebut diantaranya adalah sebagai bahan pembuktian dalam perkara hukum, bahan penelitian dan pendidikan serta dapat digunakan sebagai alat untuk analisis dan evaluasi terhadap mutu pelayanan yang diberikan oleh rumah sakit. Informed consent ini akan memberikan perlindungan hukum tidak hanya kepada pasien, namun juga melindungi tenaga kesehatan/ dokter dari tuntutan yang tidak proporsional dari pihak pasien (Hanafiah dan Amri, 2012). Selain itu, berkas rekam medis yang tidak lengkap seperti tidak adanya tanda tangan dan nama terang dokter, diagnosis dan kode diagnosis belum diisi atau belum tertulis, dan riwayat perjalanan penyakit belum terisi dengan lengkap, maka hal ini akan dapat menyebabkan terhambatnya proses pengajuan klaim kepada BPJS (Feriawati dan Kusuma, 2015).

Rumah Sakit Tk. III dr. Reksodiwiryo Padang adalah rumah sakit tingkat III di Provinsi Sumatera Barat yang berada di wilayah Kodim 0312/ Padang, dan dibawah Korem 032/ Wirabraja. Rumah sakit ini termasuk rumah sakit tipe $\mathrm{C}$ yang memiliki tugas pokok melaksanakan fungsi organic militer dan fungsi teknis medis Rumah Sakit Tk.III dr.Reksodiwiryo Padang sampai saat ini belum pernah melakukan penilaian mutu berdasarkan SPM rekam medis di rumah sakit menurut Menkes RI no 129 tahun 2008.

Dari hasil survey tanggal 23 Februari 2017 mengenai kelengkapan informed consent didapatkan bahwa dari 20 lembar informed consent rata-rata angka kelengkapan pengisian lembar informed consent sebesar $71 \%$. Rinciannya adalah identitas pemberi 
persetujuan (nama, umur, jenis kelamin, dan alamat) $65 \%$, tindakan medis $95 \%$, hubungan dengan pasien $70 \%$, identitas pasien (nama, umur, jenis kelamin, alamat, dan nomor rekam medis) $65 \%$, waktu (tempat, tanggal, bulan, tahun), saksi (nama dan tanda tangan) $70 \%$, dokter (nama, tanda tangan) $60 \%$, serta yang membuat pernyataan (nama dan tanda tangan) $75 \%$. Hal ini berarti kelengkapan pengisian lembar informed consent menurut SPM rumah sakit sebesar $100 \%$ juga tidak tercapai.

Begitu juga dengan hasil penelitian Prayogo, Lestari, dan Wariyanti (2014) di Rumah Sakit Muhammadiyah Selogiri Wonogiri mengenai kelengkapan pengisian berkas informed consent pada tindakan Open Reduction Internal Fixation (ORIF) diperoleh bahwa rata-rata angka kelengkapan berkas informed consent adalah sebesar 68,33\%. Hal ini didapatkan dari: analisis kelengkapan identifikasi pasien, item nama 45 (100\%), ketidaklengkapan jenis kelamin $8(17,8 \%)$. Kelengkapan pelaporan yang penting sepertijam dan tanggal $40(88,9 \%)$, ketidaklengkapan jenis dan isi informasi $38(84,4 \%)$. Kelengkapan autentikasi nama pasien 45(100\%), ketidaklengkapan tanda tangan dokter 31 (68,9\%). Kelengkapan pendokumentasian yang benar dengan pencatatan jelas dan terbaca 45 (100\%), dan ketidaklengkapan penggunaan garis tetap item 32 $(71,1 \%)$.

Adapun faktor-faktor penyebab ketidaklengkapan pengisian berkas rekam medis tersebut adalah adanya keterbatasan waktu yang digunakan dokter untuk mengisi berkas rekam medis, beban kerja dokter yang tinggi, belum punya ruang tunggu bagi dokter tamu sehingga dokter tidak mempunyai tempat untuk mengisi berkas rekam medis, serta kurangnya kesadaran dokter akan pentingnya kelengkapan pengisian berkas rekam medis (Pamungkas, Marwati, dan Solikhah, 2010).

\section{METODE}

Penelitian ini merupakan penelitian kombinasi yang menggabungkan metode penelitian kuantitatif dan kualitatif (mixed methods research) dengan desain sequential explanatory yang dilaksanakan di Rumah Sakit Tk.III dr. Reksodiwiryo Padang pada bulan Maret sampai dengan Juli 2017. Pada tahap pertama dilakukan dengan menggunakan metode kuantitatif dan tahap kedua dengan metode kualitatif (Sugiyono, 2013). Penelitian kuantitatif berperan untuk memperoleh data jumlah output yang bersifat deskriptif dengan teknik pengambilan sampel secara simple random sampling, dengan jumlah sampel 67 lembar informed consent pada pasien bedah.

Jumlah sampel ditentukan dengan menggunakan rumus besar sampel deskriptif kategorik (Dahlan, 2010) dengan rumus sebagai berikut:

$$
n=\frac{Z \alpha^{2} P \times Q}{d^{2}}
$$

Keterangan :

$\mathrm{n} \quad=$ Jumlah sampel yang dibutuhkan

$Z \alpha^{2}=$ Nilai baku distribusi normal $=1,96(95 \%)$

$\mathrm{P} \quad=$ Proporsi kategori variabel yang diteliti

$\mathrm{Q}=1-\mathrm{P}$

$\mathrm{d} \quad=$ Presisi $=10 \%=0,1$

Dengan proporsi variabel kelengkapan lembar informed consent yang sesuai standar (100\%) pada penelitian sebelumnya sebesar $80 \%=0,8$ (Herfiyanti, 2015).

Untuk jumlah sampel yang perlu diambil sebanyak 61 sampel. Selain itu, untuk mengantisipasi drop out maka jumlah sampel di atas ditambah 10\% sehingga menjadi 67 sampel.

Metode kualitatif untuk mendapatkan informasi mendalam tentang input dan proses dalam penyelenggaraan sistem pelayanan rekam medis berdasarkan SPM rekam medis di rumah sakit. Teknik penentuan informan yang digunakan secara purposive sampling dengan jumlah informan 15 orang. Pengolahan data diolah dengan cara reduksi data, penyajian data, penarikan kesimpulan dan verifikasi. Analisis data yang dipakai untuk menganalisis data penelitian ini dilakukan dengan tekhnik analisis isi. Peneliti menggunakan triangulasi sebagai teknik untuk mengecek keabsahan data yakni triangulasi sumber dan triangulasi metode.Metode pengumpulan data dilakukan melalui wawancara mendalam, observasi, dan telaah dokumen.

\section{HASIL}

\section{Hasil Penelitian Kuantitatif}

Untuk mengetahui distribusi frekuensi kelengkapan pengisian lembar informed consent pasien bedah dapat dilihat pada tabel 1 . 
Tabel 1. Distribusi Frekuensi Kelengkapan Pengisian Lembar Informed Consent Pasien Bedah di RS Tk.III dr. Reksodiwiryo

\begin{tabular}{|c|c|c|c|c|c|}
\hline \multirow{3}{*}{ No } & \multirow{3}{*}{ Item Penilaian } & \multicolumn{4}{|c|}{ Lengkap/Tidak Lengkap } \\
\hline & & \multicolumn{2}{|c|}{ Lengkap } & \multicolumn{2}{|c|}{ Tidak Lengkap } \\
\hline & & $\begin{array}{c}\text { Jum- } \\
\text { lah }\end{array}$ & $\%$ & $\begin{array}{c}\text { Jum- } \\
\text { lah }\end{array}$ & $\%$ \\
\hline \multirow[t]{6}{*}{1} & Identitas Pasien & & & & \\
\hline & a. Nama & 67 & 100,0 & 0 & 0,0 \\
\hline & b. Umur & 60 & 89,6 & 7 & 10,4 \\
\hline & c. Jenis Kelamin & 42 & 62,7 & 25 & 37,3 \\
\hline & d. Alamat & 22 & 32,8 & 45 & 67,2 \\
\hline & e. No.Rekam Medis & 55 & 82,1 & 12 & 17,9 \\
\hline \multirow[t]{6}{*}{2} & $\begin{array}{l}\text { Identitas Keluarga } \\
\text { Pasien }\end{array}$ & & & & \\
\hline & a. Nama & 65 & 97,0 & 2 & 3,0 \\
\hline & b. Umur & 63 & 94,0 & 4 & 6,0 \\
\hline & c. Jenis Kelamin & 50 & 74,6 & 17 & 25,4 \\
\hline & d. Alamat & 40 & 59,7 & 27 & 40,3 \\
\hline & e. Hub dengan Pasien & 59 & 88,1 & 8 & 11,9 \\
\hline 3 & $\begin{array}{l}\text { Nama Dokter Pemberi } \\
\text { Informasi }\end{array}$ & 48 & 71,6 & 19 & 28,4 \\
\hline \multirow[t]{12}{*}{4} & Jenis Informasi & & & & \\
\hline & 1) Diagnosis & 54 & 80,6 & 13 & 19,4 \\
\hline & 2) Dasar Diagnosis & 35 & 52,2 & 32 & 47,8 \\
\hline & $\begin{array}{l}\text { 3) Tindakan Kedok- } \\
\text { teran }\end{array}$ & 47 & 70,1 & 20 & 29,9 \\
\hline & 4) Indikasi Tindakan & 30 & 44,8 & 37 & 55,2 \\
\hline & 5) Tata Cara & 37 & 55,2 & 30 & 44,8 \\
\hline & 6) Tujuan & 28 & 41,8 & 39 & 58,2 \\
\hline & 7) Risiko & 35 & 52,2 & 32 & 47,8 \\
\hline & 8) Komplikasi & 44 & 65,7 & 23 & 34,3 \\
\hline & 9) Prognosis & 38 & 56,7 & 29 & 43,3 \\
\hline & $\begin{array}{l}\text { 10) Alternatif dan } \\
\text { Risiko }\end{array}$ & 17 & 25,4 & 50 & 74,6 \\
\hline & $\begin{array}{l}\text { 11) Hal Lain untuk } \\
\text { menyelamatan } \\
\text { pasien }\end{array}$ & 37 & 55,2 & 30 & 44,8 \\
\hline 4 & $\begin{array}{l}\text { Tanda Tangan Pem- } \\
\text { beri Informasi }\end{array}$ & 40 & 59,7 & 27 & 40,3 \\
\hline 5 & $\begin{array}{l}\text { Tanda Tangan Pem- } \\
\text { beri Persetujuan }\end{array}$ & 57 & 85,1 & 10 & 14,9 \\
\hline \multirow[t]{2}{*}{6} & Tanggal Persetujuan & 40 & 59,7 & 27 & 40,3 \\
\hline & Rata-rata & & 66,3 & & 33,7 \\
\hline
\end{tabular}

Dari tabel 1 diketahui bahwa angka kelengkapan pengisian lembar Informed Consent terendah terdapat pada alternatif risiko dan alamat pasien masing-masing yakni 25,4\% dan 32,8\%. Adapun angka kelengkapan pengisian lembar Informed Consent pasien rawat inap di Rumah Sakit Tk.III dr. Reksodiwiryo masih termasuk belum lengkap karena persentase angka kelengkapan pengisian lembar Informed Consent hanya diperoleh sebesar 66,3\%. Artinya, angka kelengkapan pengisian lembar Informed Consent rekam medis belum mencapai standar pelayanan minimal rekam medis di rumah sakit yakni sebesar 100\%.

\section{Hasil Penelitian Kualitatif Input (Man dan Methode)}

Berdasarkan kuantitas jumlah petugas rekam medis masih belum mencukupi karena pekerjaan di bagian rekam medis ini banyak dan jumlah pasien juga semakin meningkat. Dari segi kualitas masih kurang karena masih ditemukan petugas yang berlatar belakang pendidikan SMA. Meskipun ada yang berlatar belakang D-III dan S-1, namun tidak semua berasal dari tamatan ilmu rekam medis. Selain itu, kegiatan pelatihan tentang penyelenggaraan sistem pelayanan rekam medis belum pernah diadakan di Rumah Sakit Tk.III dr. Reksodiwiryo Padang. Begitu juga dengan sistem reward and punishment juga belum pernah diterapkan.

Methode dalam penyelenggaraan sistem pelayanan rekam medis Rumah Sakit Tk.III dr. Reksodiwiryo dilaksanakan dengan cara manual dan komputerisasi. Berdasarkan wawancara, telaah dokumen, maupun observasi bahwa SOP penyelenggaraan rekam medis ada tersedia di instalasi rekam medis.

\section{Proses (Pencatatan dan Analisis Isi Rekam Medis)}

Pencatatan dalam penyelenggaraan sistem pelayanan rekam medis Rumah Sakit Tk.III dr. Reksodiwiryo masih belum terlaksana dengan baik. Dari hasil telaah dokumen ditemukan pencatatan identitas pasien seperti alamat yang tidak lengkap, ditemukan masih banyak tenaga medis tidak melengkapi nama atau tanda tangan serta waktu saat memberikan pelayanan. Padahal, setiap pencatatan rekam medis harus dibubuhi nama, waktu dan tanda tangan dokter atau tenaga kesehatan tertentu yang memberikan pelayanan kesehatan secara langsung. Hal ini diperlukan untuk memudahkan sistem pertanggungjawaban atas pencatatan tersebut. Berdasarkan observasi maupun wawancara, proses pencatatan ada yang manual dan ada memakai 
komputer. Rekam medis dibuat oleh petugas rekam medis, perawat, dan dokter. Kendalanya dalam pencatatan adalah lupa mengisi. Apalagi jika ada kasus darurat maka tindakan diutamakan terlebih dahulu. Pencatatan rekam medis dilakukan setelah tindakan.

Analisis isi rekam medis dalam penyelenggaraan sistem pelayanan rekam medis Rumah Sakit Tk.III dr. Reksodiwiryo tidak dilaksanakan oleh petugas rekam medis. Kendalanya karena dituntut oleh banyaknya pekerjaan lain.

\section{PEMBAHASAN}

\section{Kuantitatif}

Menurut Permenkes No.290/Menkes/Per/III/2008 Pasal 1, persetujuan tindakan kedokteran (Informed Consent) adalah persetujuan yang diberikan oleh pasien atau keluarga terdekat setelah mendapat penjelasan secara lengkap, mengenai tindakan kedokteran atau kedokteran gigi yang akan dilakukan terhadap pasien. Menurut Konsil Kedokteran Indonesia suatu persetujuan dianggap sah apabila pasien telah diberi penjelasan atau informasi, pasien atau yang sah mewakilinya dalam keadaan cakap (kompeten) untuk memberikan keputusan atau persetujuan, persetujuan harus dibrikan secara sukarela.

Menurut Herfiyanti (2015) bahwa kelengkapan pengisian formulir Informed Consent tindakan bedah terdiri dari: identitas pasien (nama pasien, umur, jenis kelamin, alamat, nomor rekam medis), informasi identitas keluarga pasien (nama pemberi persetujuan, umur, jenis kelamin, alamat, hubugan dengan pasien, tanggal persetujuan), jenis tindakan, jenis informasi (diagnosis kerja, diagnosis banding, tindakan kedokteran, indikasi tindakan, tata cara, tujuan, risiko tindakan, komplikasi, prognosis, alternatif dan risiko, dan lain-lain), serta informasi autentifikasi (nama dan tanda tangan dokter, nama dan tanda tangan pasien atau keluarga pasien, dan nama serta tanda tangan saksi-saksi).

Wulandari dan Sugiarsi(2014) catatan medis yang terdapat dalam berkas rekam medis dikatakan memiliki keabsahan bilamana tenaga kesehatan yang merawat pasien atau surat persetujuan yang diberikan pasien atau wali dalam rekam medis diakhiri dengan membubuhkan atau mengabsahkan tanda tangan disertai nama terang.
Angka kelengkapan pengisian lembar Informed Consent pasien rawat inap di Rumah Sakit Tk.III dr. Reksodiwiryo tahun 2017 masih termasuk belum lengkap karena persentase angka kelengkapan pengisian lembar Informed Consent hanya diperoleh sebesar $66,3 \%$. Artinya, angka kelengkapan pengisian lembar Informed Consent rekam medis belum mencapai standar pelayanan minimal rekam medis di rumah sakit yakni sebesar $100 \%$.

Hasil penelitian ini sesuai dengan penelitian Prayogo, dkk (2014) di Rumah Sakit Muhammadiyah Selogiri Wonogiri mengenai kelengkapan pengisian berkas informed consent pada tindakan Open Reduction Internal Fixation (ORIF) diperoleh ratarata angka kelengkapan lembar informed consent sebesar $68,33 \%$. Hasil ini juga belum mencapai SPM kelengkapan lembar informed consent di rumah sakit yakni $100 \%$.

Ketidaklengkapan lembar Informed Consent berdampak pada menurunnya kualitas mutu rekam medis sehingga bisa berpengaruh pada proses penilaian akreditasi rumah sakit, selain itu juga berdampak pada jaminan kepastian hukum bagi pasien, tenaga rekam medis, tenaga medis, maupun pihak rumah sakit. Apabila terjadi sengketa dikemudian hari, alat bukti berupa Informed Consent menjadi kurang kuat akibat tidak jelasnya identitas yang menandatangani baik dari pihak pasien maupun dokter yang menangani pasien. Selain itu, berdasarkan Permenkes No 269 (2008) pasal 13 dijelaskan bahwa adanya sangsi administratif pada pelanggaran pengisian Informed Consent antara lain, terhadap dokter yang melakukan tindakan medik tanpa persetujuan dari pasien atau keluarganya, dapat dikenakan sanksi administratif berupa pencabutan izin praktek.

Upaya yang perlu dilakukan agar pengisian lembar Informed Consent lengkap antara lain diadakannya sosialisasi secara rutin dan terjadwal kepada perwakilan tim komite medik, perawat, dan petugas rekam medis terkait dengan pentingnya kelengkapan pengisian dokumen rekam medis termasuk juga lembar Informed Consent, perlu adanya petugas khusus untuk melakukan analisis kelengkapan lembar Informed Consent dengan menyediakan lembaran checklist kelengkapan, dan menerapkan sistem reward and punishment untuk meningkatkan kinerja petugas. 


\section{Kualitatif}

Man yaitu tenaga kerja manusia, baik tenaga kerja pimpinan maupun tenaga kerja operasional/ pelaksana (Hasibuan, 2009). Tenaga kerja adalah orang yang melaksanakan dan mengisi serta mengelola rekam medis. Tenaga kerja yang terlibat dalam penyelenggaraan rekam medis terdiri dari dokter umum, dokter spesialis, dokter gigi dan dokter spesialis yang bekerja di rumah sakit, dokter tamu yang di rumah sakit, dan residen yang sedang melaksanakan kepaniteraan medis. Tenaga paramedis perawatan dan paramedis non perawatan yang langsung terlibat dalam pelayanan kepada psien antara lain : perawat, perawat gigi, bidan, tenaga labotarium, gizi, anesthesia, penata rontgent, rehabilitasi medis.

Tanggung jawab utama kelengkapan rekam medis terletak pada dokter yang merawat. Dokter mencatat riwayat penyakit, hasil pemeriksaan fisik, terapi, serta semua tindakan yang diberikan kepada pasien pada lembaran-lembaran rekam medis dan menandatanganinya. Perawat atau bidan mencatat pengamatan pertolongan yang diberikan kepada pasien, serta mengisi lembaran grafik tentang suhu, nadi, dan pernafasan, dan juga menambah lembaranlembaran rekam medis sesuia kebutuhan pelayanan. Selanjutnya analisis kelengkapan rekam medis dan pengolahan data rekam medis dilakukan oleh petugas rekam medis (Depkes RI, 1997).

Petugas rekam medis menjadi aspek utama dalam sirkulasi rekam medis sebuah rumah sakit. Petugas rekam medis mempunyai tugas dan tanggung jawab yang besar dalam menjaga keutuhan sebuah rekam medis. Petugas rekam medis diharapkan benar-benar mengetahui seluk beluk dari rekam medis secara luas dan mendalam. Menurut Permenkes RI No 55 Tahun 2013 tentang Penyelenggaraan Pekerjaan Perekam Medis pada pasal tiga dijelaskan bahwa seorang pegawai rekam medis harus memiliki kualifikasi pendidikan antara lain : diploma 3 (D3) Rekam Medis dan Informasi Kesehatan dengan gelar Ahli Madya, diploma 4 (D4) Manajemen Informasi Kesehatan dengan gelar Sarjana Terapan MIK/ STr, strata 1 (S1) Manajemen Informasi Kesehatan dengan gelar Sarjana Manajemen Informasi Kesehatan, dan strata 2 (S2) Manajemen Informasi Kesehatan dengan gelar Magister Manajemen Informasi Kesehatan.

Menurut Kemenkes RI No.377/Menkes/SK/ III/2007, seorang pegawai rekam medis atau perekam medis harus memiliki kompetensi.
Kompetensi perekam medis itu harus mampu untuk menetapkan kode penyakit dan tindakan dengan tepat sesuai dengan klasifikasi yang diberlakukan di Indonesia (ICD-10 dan ICD-9-CM), melakukan tugas dalam memberikan pelayanan rekam medis dan informasi kesehatan yang bermutu tinggi dengan memperhatikan perundangan dan etika profesi yang berlaku, mengelola rekam medis dan informasi kesehatan untuk memenuhi kebutuhan layanan medis, administrasi, dan kebutuhan informasi kesehatan sebagai bahan pengambilan keputusan di bidang kesehatan (Kemenkes RI, 2007).

Selain itu, kompetensi yang diharapkan dari seorang perekam medis adalah menjaga mutu rekam medis; menggunakan statistik kesehatan untuk menghasilkan informasi dan perkiraan (forecasting), mengelola unit kerja yang berhubungan dengan perencanaan, pengorganisasian, penataan dan pengontrolan unit kerja manajemen informasi kesehatan (MIK) rekam medis di instalasi pelayanan kesehatan, serta berkolaborasi inter dan intra profesi yang terkait dalam pelayanan kesehatan (Kemenkes RI, 2007).

Berdasarkan data tenaga dari profil rumah sakit tidak ada data petugas rekam medis. Oleh karena itu, dilakukan penghitungan data rekam medis dari kepegawaian. Adapun jumlah petugas rekam medis Rumah Sakit Tk. III dr. Reksodiwiryo Padang adalah 23 orang. Jumlah tenaga rekam medis berdasarkan pendidikan, tamatan SMA sebanyak 21\%, D-III rekam medis sebanyak $52 \%$, serta tamatan S-1 (sarjana) sebanyak 26\%.

Hal ini tidak sesuai dengan Permenpan tentang Perekam Medis tahun 2013 yang menjelaskan bahwa jumlah tenaga rekam medis untuk rumah sakit umum tipe $\mathrm{C}$ adalah sebanyak 30 orang tenaga rekam medis terampil dengan latar belakang pendidikan minimal D-III Rekam Medis, dan sebanyak enam orang tenaga ahli dengan latar belakang pendidikan S-1 Rekam Medis. Dengan demikian kebutuhan akan kualitas tenaga di instalasi rekam medis Rumah Sakit Tk. III Dr. Reksodiwiryo belum dapat terpenuhi.

Mengenai pelatihan, sesuai dengan penelitian Budiyanti dan Damayanti (2015) tentang penilaian kebutuhan pelatihan pada tingkat individu petugas rekam medis di Rumah Sakit Undaan Surabaya bahwa kebutuhan pelatihan petugas rekam medis sangat diperlukan karena tingkat pengetahuan mengenai pengelolaan rekam medis dan keterampilan dalam melakukan pekerjaan tekhnis maupun non tekhnis masih termasuk kategori kurang. Adapun 
kebutuhan pelatihan yang diperlukan meliputi pelatihan pengetahuan sistem identifikasi berkas, alur rekam medis, penulisan rekam medis, sistem pengembalian, sistem penyimpanan, tugas dan tanggung jawab tiap bagian kerja, kepatuhan petugas sesuai SOP, softskill terkait keramahan, komunikasi efektif, dan kedisiplinan.

Dari hasil penelitian dapat diketahui bahwa jumlah tenaga rekam medis masih belum mencukupi, dari segi kualitas tenaga masih kurang karena masih ada yang berlatar belakang pendidikan SMA. Untuk mengatasi kekurangan jumlah tenaga perlu adanya perencanaan penambahan tenaga. Mengingat penambahan jumlah tenaga tidak bisa dalam waktu singkat, maka upaya yang dapat dilakukan adalah meningkatkan efektifitas petugas dengan memberikan penjelasan tentang tugas pokok dan fungsi serta uraian tugas masing-masing petugas secara tertulis, sehingga jelas tugas yang akan dikerjakannya. Selanjutnya, perlu ditempel/dipajang tentang SOP dan alur penyelenggaraan rekam medis di ruang kerja petugas rekam medis sebagai pedoman petugas dalam melaksanakan tugas.

Selain itu, kegiatan pelatihan tentang rekam medis belum pernah diadakan di rumah sakit. Padahal adanya pelatihan diperlukan untuk meningkatkan kualitas SDM. Sistem reward dan punishment juga belum ada. Sistem reward dan punishment seharusnya perlu diterapkan agar dapat meningkatkan motivasi dan kinerja petugas rekam medis.

Methode yang dimaksud adalah jenis rekam medis yang digunakan dan Ketersediaan Prosedur Tetap (PROTAP)/ Standar Operasional Prosedur (SOP) Rekam Medis. Cara untuk melaksanakan rekam medis di intansi kesehatan dalam perkembangannya terbagi dalam dua jenis praktik : praktik rekam medis manual dan modern. Praktik rekam medis manual maksudnya adalah bentuk rekaman dilaksanakan melalui rekam medis kertas, sedangkan praktik rekam medis modern orientasi pengelolaan berbasis informasi yang dilakukan melalui komputer dan disebut manajemen informasi kesehatan/MIK (Hatta, 2008).

Dalam praktik manajemen rekam kesehatan secara manual, pengumpulan data dilakukan melalui format kertas serta disimpan dalam map (folder). Adapun Praktek rekam medis di era modern mengumpulkan, menyimpan dan menganalisis data/informasi melalui rekam kesehatan elektronik (RKE) yang interaktif (Hatta, 2008).
PROTAP/ SOP berisi langkah-langkah kerja yang dikerjakan pada pelayanan rekam medis. Prosedur tetap penyelenggaran rekam medis terdiri dari beberapa standar antara lain : pendaftaran pasien baru, pendaftaran pasien lama, prosedur pendaftaran, prosedur pendaftaran pasien dengan perjanjian, prosedur pendaftaran dini, prosedur registrasi rawat inap, prosedur pembuatan sertifikat kelahiran, prosedur registrasi kelahiran, prosedur pendistribusian rekam medis, prosedur register penomoran, prosedur pengkodean dan indeks penyakit, serta prosedur pengkodean diangnosa penyakit rawat jalan.

Selain itu, prosedur tetap penyelenggaran rekam medis antara lain terdapat standar-standar seperti pembuatan laporan morbiditas pasien rawat jalan, penataan berkas rekam medis rawat jalan, penyelesaian resume dan laporan kematian, pengodean dan indeks penyakit rawat inap, prosedur pencarian rekam medis, penyimpanan rekam medis, mikrofilmisasi berkas, penyusutan arsip rekam medis, sensus harian dan rawat jalan, pembuatan laporan kegiatan rumah sakit, peminjaman rekam medis, dan pembuatan laporan data individual morbiditas (Depkes RI, 1997).

Dari hasil penelitian diketahui bahwa methode dalam penyelenggaraan sistem pelayanan rekam medis Rumah Sakit Tk.III dr. Reksodiwiryo dilaksanakan dengan dua cara yaitu ada yang manual dan komputerisasi. Pelaksanaan pencatatan dokumen rekam medis rekam medis umumnya secara manual, kecuali pengisian data identitas pasien saat pendaftaran pasien dilaksanakan secara komputerisasi.

SOP sistem pelayanan rekam medis ada tersedia dan sudah dibagi-bagikan ke setiap unit. Adapun tujuan SOP adalah untuk sebagai acuan dalam melaksanakan tugas, menghindarkan kesalahan dan kebingungan dalam mengerjakan tugas, menjamin pelaksanaan pekerjaan menurut aturan yang benar secara efisien, memperjelas garis tanggung jawab dan sebagai perlindungan hukum baik bagi karyawan maupun institusi pelayanan kesehatan (Sabarguna, 2003). Namun, sosialisasi dan pelaksanaan SOP ini masih kurang. Upaya yang harus dilakukan adalah perlu adanya pertemuan atau rapat untuk mengevaluasi SOP agar dapat meningkatkan mutu rekam medis.

Proses adalah semua kegiatan yang dilaksanakan secara profesional oleh tenaga kesehatan (dokter, perawat, dan tenaga profesional lain) dan 
interaksinya dengan pasien. Pendekatan proses adalah pendekatan paling langsung terhadap mutu pelayanan (Wijono,1999). Penyelenggaraan rekam medis meliputi: penerimaan pasien, pencatatan, penyimpanan dan pengambilan kembali. Pencatatan adalah pendokumentasian segala informasi medis pasien ke dalam rekam medis yang akan menjadi bahan informasi. Catatan berdasarkan sumber datanya dibedakan menjadi catatan sosial dan catatan medis. Catatan sosial diperoleh saat penerimaan pasien di TPP yang meliputi nama, alamat, umur, agama, dan pekerjaan. Sedangkan data medis diperoleh pasien setelah mendapatkan pelayanan dari dokter, perawat atau petugas lainnya seperti petugas laboratorium dan radiologi.

Secara garis besar penyelenggaraan rekam medis dalam Permenkes No 269 tahun 2008, diatur sebagai berikut antara lain rekam medis adalah berkas yang berisikan catatan dan dokumen tentang identitas pasien, pemeriksaan, pengobatan, tindakan, dan pelayanan lain yang telah diberikan pada pasien. Rekam medis harus dibuat secara tertulis, lengkap dan jelas atau secara elektronik. Hal ini dimaksudkan agar data yang dicatat masih original dan tidak ada yang terlupakan karena adanya tanggung jawab. Namun dari hasil penelitian masih ada ditemukan rekam medis pasien yang belum lengkap.

Tanggung jawab rekam medis (Suprapti, 2001) bagi dokter yang merawat antara lain bertanggung jawab terhadap kelengkapan dan kebenaran isi rekam medis. Pencatatan beberapa keterangan medis seperti riwayat penyakit, pemeriksaan fisik, dan ringkasan keluar (resume) bisa didelegasikan kepada dokter lain dan data itu harus dipelajari kembali, dikoreksi, dan ditandatangani oleh dokter yang merawat.

Isi rekam medis untuk dan perawatan satu hari sekurang-kurangnya memuat identitas pasien, tanggal dan waktu, hasil anamnesis, mencakup sekurang-kurangnya keluhan dan riwayat penyakit, hasil pemeriksaan fisik dan penunjang medis, diangnosis, rencana penatalaksanaan, pengobatan dan tindakan, persetujuan tindakan bila diperlukan, catatan observasi klinis dan hasil pengobatan, ringkasan pulang nama dan tanda tanggan dokter, dokter gigi atau tenaga kesehatan tertentu yang memberikan pelayanan kesehatan, pelayanan lain yang dilakukan oleh tenaga kesehatan tertentu, pasien khusus gigi dilengkapi dengan odontogram klinik (Permenkes, 2008).

Dari hasil penelitian dapat diketahui bahwa pencatatan dalam penyelenggaraan sistem pelayanan rekam medis Rumah Sakit Tk.III dr. Reksodiwiryo masih belum terlaksana dengan baik. Dari hasil telaah dokumen ditemukan pencatatan identitas pasien seperti alamat yang tidak lengkap. Dari hasil telaah dokumen rekam medis pasien juga ditemukan masih banyak tenaga medis ini tidak melengkapi nama atau tanda tangan serta waktu saat memberikan pelayanan. Padahal, setiap pencatatan rekam medis harus dibubuhi nama, waktu dan tanda tangan Dokter atau tenaga kesehatan tertentu yang memberikan pelayanan keehatan secara langsung. Hal ini diperlukan untuk memudahkan sistem pertanggungjawaban atas pencatatan tersebut. Jika terdapat kesalahan pencatatan, maka pembetulan hanya dapat dilakukan dengan cara pencoretan tanpa menghilangkan catatan yang dibetulkan dan dibubuhi paraf dokter, dokter gigi atau tenaga kesehatan tertentu yang bersangkutan. Sarana pelayanan kesehatan wajib menyediakan fasilitas yang diperlukan dalam rangka penyelenggaraan rekam medis (Permenkes, 2008).

Kendala dalam pencatatan adalah lupa mengisi, apalagi kalau ada kasus yang darurat maka tindakan dikerjakan terlebih dahulu baru mengisi rekam medis. Seharusnya ada yang mengingatkan, misalnya perawat atau dokter umum yang mendampingi dokter spesialis saat memberikan tindakan. Cara pembagian tugas pengisian rekam medis sesuai dengan shift, namun harus ada komunikasi yang jelas.

Analisis isi rekam medis terdapat tiga jenis analisis yaitu : analisis kuantitatif, analisis kualitatif, dan analisis statistik (Huffman, 1994). Analisis kuantitatif merupakan analisis yang ditujukan kepada jumlah lembaran-lembaran rekam medis sesuai dengan lamanya perawatan meliputi kelengkapan lembaran medis, paramedis dan penunjang sesuai prosedur yang ditetapkan. Petugas akan menganalisis setiap berkas yang diterima apakah lembaran rekam medis yang seharusnya ada pada rekam medis seseorang pasien sudah ada atau belum. Ketidaklengkapan berkas pasien dari lembaran tertentu agar segera menghubungi ke ruang rawat inap dimana pasien dirawat (Huffman, 1994).

Komponen analisis kuantitatif (Huffman, 1994) yakni : mengoreksi identifikasi pasien pada setiap formulir; memeriksa setiap halaman catatan medis minimal nama dan nomor rekam medis (kehadiran semua laporan yang diperlukan terdapat laporan tertentu yang umumnya ada pada catatan medis semua fasilitas, misalnya laporan riwayat penyakit, pemeriksa fisik, catatan kemajuan dan resume; 
otentikasi yang diharuskan pada semua entri (bisa berupa tanda tangan, stempel karet yang hanya dipegang oleh pemilik, kalau diperlukan tanda tangan pendamping, kedua tanda tangan harus ada, disamping catatan mengenai pemeriksa entri, misalnya telah diperiksa, disetujui atau menjalankan perintah seperti tercatat).

Analisis Kualitatif merupakan pemeriksa entri rekam medis untuk mencari inkonsitensi dan isi yang bisa menyebabkan catatan tersebut tidak lengkap atau tidak tepat. Komponen-komponen analisis kualitatif, yakni (Huffman, 1994) : pencatatan yang lengkap dan konsisten tentang diagnostik pernyataan-pernyataan diagnostik dibuat pada hampir semua bagian rekam medis; konsisten entri oleh semua penyedia asuhan kesehatan konsistensi adalah kesesuaian satu bagian dengan bagian lainnya dan bagian keseluruhan; uraian dan pembenaran perawatan pasien dirumah sakit rekam medis harus menguraikan dan menjadi alasan yang membenarkan arah hospitalisasi pasien; pencatatan semua hal yang diperlukan untuk "informed consent" yakni informasi mengenai persetujuan pasien akan pengobatan harus dituliskan dengan hati-hati; penerapan cara dokumentasi yang baik yang mana rekam medis harus memiliki keterbacaan atau penulisan yang bisa dibaca, penggunaan tinta permanen, dan pengsisian formulir yang lengkap, rekam medis tidak boleh berisi komentar yang merendahkan atau mengkritik, adanya potensi "compensable event".

Dari hasil penelitian diperoleh bahwa analisis isi rekam medis tidak dilaksanakan oleh petugas rekam medis. Kendalanya karena dituntut dengan pekerjaan lain. Upaya yang harus dilakukan, perlu ada kejelasan dalam penanggung jawab setiap pekerjaan di bagian rekam medis. Tugas pokok dan fungsi setiap petugas harus jelas dan ditetapkan oleh kepala ruangan rekam medis sehingga kegiatan analisis rekam medis ini dapat dipertanggungjawabkan oleh petugas yang telah ditunjuk.

Sebaiknya analisis isi rekam medis ini dilakukan berkala setiap bulan. Dengan menganalisis isi rekam medis, maka dengan mudah dalam mengevaluasi pengisian rekam medis. Setelah dievaluasi nanti akan diperoleh bahwa rekam medis tersebut lengkap atau tidak sesuai standar pelayanan minimal rekam medis di rumah sakit. Rekam medis yang lengkap ini dapat menghindari keadaan yang merugikan bagi pasien maupun pihak rumah sakit apabila ada yang memaksa fasilitas atau penyedia layanan dalam menghadapi tuntutan pidana atau perdata.

\section{SIMPULAN}

Kelengkapan pengisian lembar Informed Concent, diperoleh sebesar 66,3\%. Artinya, angka kelengkapan pengisian lembar Informed Consent rekam medis belum mencapai standar pelayanan minimal rekam medis di rumah sakit yakni sebesar $100 \%$. Hal ini disebabkan karena :

1. Petugas rekam medis (Man) secara kuantitas masih kurang, pengembangan sumber daya manusia/tenaga berupa pelatihan belum pernah dilakukan, serta sistem reward dan punishment tidak ada.

2. SOP penyelenggaraan rekam medis tersedia di intalasi rekam medis, namun belum disosialisasikan kepada semua petugas rekam medis dan tenaga medis yang ada sehingga penyelenggaraannya belum sepenuhnya sesuai dengan SOP.

3. Kendala proses pencatatan sering terjadi lupa dalam pengisian lembar informed consent.

4. Analisis isi rekam medis dalam penyelenggaraan sistem pelayanan rekam medis Rumah Sakit Tk.III dr. Reksodiwiryo belum optimal.

\section{DAFTAR PUSTAKA}

Budiyanti, H dan Damayanti, NA. (2015). Penilaian Kebutuhan Pelatihan pada Tingkat Individu Petugas Rekam Medis. Jurnal Administrasi Kesehatan Indonesia Vol. 3 No.1, Hal 70-79. [Online]. Diakses dari : Http//media.neliti. com. 13 Maret 2017.

Dahlan, S. (2010). Statistik untuk Kedokteran dan Kesehatan : Deskriptif, Bivariat, dan Multivariat. Edisi 5. Jakarta : Salemba Medika.

Depkes RI. (1997). Pedoman Pengelolaan Rekam Medis Rumah Sakit Di Indonesia. Jakarta: Direktorat Jendral Pelayanan Medik.

DPR RI. (2009). Undang-Undang Republik Indonesia Nomor 44 Tahun 2009 tentang Rumah Sakit. Jakarta.

Feriawati, P dan Kusuma, AP. (2015). Faktor Faktor Keterlambatan Pengklaiman BPJS Di Rumah Sakit Bhayangkara Semarang Tahun 2015. [Online]. Diakses dari : Http://eprints. dinus.ac.id. 15 Januari 2017.

Hanafiah, MJ dan Amri, A. (2012). Etika kedokteran dan Hukum Kesehatan. Edisi 4. Jakarta: Penerbit Buku Kedokteran EGC. 
Hasibuan, Malayu.S.P. 2009. Manajemen : Dasar, Pengertian, dan Masalah Edisi Revisi. Jakarta: Bumi Aksara

Hatta, GR. (2008). Pedoman Manajemen Informasi Kesehatan di Sarana Pelayanan Kesehatan. Jakarta: Universitas Indonesia.

Herfiyanti, L. (2015). Kelengkapan Informed Consent Tindakan Bedah Menunjang Akreditasi JCI Standar HPK 6 Pasien Orthopedi. Jurnal Manajemen Informasi Kesehatan Indonesia Vol.3 No.2, hal 81-87.

Huffman, EK. (1994). Health Information Management. Tenth Edition. Physicians Record Company. Berwyn : Illinois. Terjemahan Erkadius. (2013). Manajemen Informasi Kesehatan I. Diktat Perkuliahan. Padang: Apikes Iris.

Huffman, EK. (1994). Health Information Management. Tenth Edition. Physicians Record Company. Berwyn : Illinois. Terjemahan Erkadius. (2011). Manajemen Informasi Kesehatan II. Diktat Perkuliahan. Padang: Apikes Iris.

Huffman, EK. (1994). Health Information Management. Tenth Edition. Physicians Record Company. Berwyn : Illinois. Terjemahan Erkadius. (2011). Manajemen Informasi Kesehatan III. Diktat Perkuliahan. Padang: Apikes Iris.

Kemenkes RI. (2008). Peraturan Menteri Kesehatan Republik Indonesia Nomor 129/Menkes/SK/ II/2008 tentang Standar Pelayanan Minimal Rumah Sakit. Jakarta. Direktorat Jendral Pelayanan Medik.

Kemenkes RI.(2007). Keputusan Menteri Kesehatan RINo 337 Tahun 2007 tentang Standar Profesi Perekam Medis dan Informasi Kesehatan. Jakarta: Badan Pengembangan dan Pemberdayaan SDM Kesehatan.
Pamungkas TW, Marwati T, dan Solikhah. (2010). Analisis Ketidaklengkapan Pengisian Berkas Rekam Medis di Rumah Sakit PKU Muhammadiyah Yogyakarta. Jurnal Kesmas Vol 4 No 1 Januari 2010 hal 17-28. [Online]. Diakses dari : Http://journal.uad.ac.id. 15 Januari 2017.

Permenkes RI. (2008). Rekam Medis. Jakarta: Direktorat Jendral Pelayanan Medik.

Permenkes RI. (2013). Peraturan Menteri Kesehatan No 55 Tahun 2013 tentang Penyelenggaraan Pekerjaan Perekam Medis. Jakarta. Direktorat Jendral Pelayanan Medik.

Prayogo, PD, Lestari, T, dan Wariyanti, AS. (2015). Analisis Kelengkapan Pengisian Formulir Informed Consent Tindakan Open Reduction Internal Fixtion/ORIF. Jurnal Rekam Medis, Vol IX No.2, hal 41-45. [Online]. Diakses dari : Http://ejurnal.stikesmhk.ac.id. 12 Januari 2017.

Sabarguna, B. (2003). Organisasi dan Manajemen Rumah Sakit. Yogyakarta: Konsorium Rumah Sakit Islam Jateng DIY.

Sugiyono. (2013). Metode Penelitian Kuantitatif, Kualitatif. dan R\&D. Bandung: Alfabeta.

Suprapti, SR. 2001. Etika Kedokteran Indonesia. Yayasan Bina Pustaka Sarwono Prawirodihardjo. Jakarta

Wijono, D. (1999). Manajemen Mutu Pelayanan Kesehatan. Surabaya: Airlangga University Press.

Wulandari, R dan Sugiarsi, S (2014). Analisis Pengisian Formulir Resume Medis Diabetes Mellitus Pasien Rawat Inap. Jurnal Manajemen Informasi Kesehatan (JMIKI). Vol 2 No. 4 